\title{
Influence of Pruning Intensity, Crop Load and Fertigation on Quality Attribute of Pomegranate Cv. Bhagwa
}

\author{
Dinesh Nagar*, K. K. Meena, S. Mukherjee and Sourabh Garg
}

Rajasthan Agricultural Research Institute (RARI), Durgapura, Jaipur 302018, India

*Corresponding author

\section{A B S T R A C T}

Keywords

Fertigation, Crop load, Pruning,

Sugar content,

Titrable acidity,

Ascorbic acid

Article Info

Accepted:

15 November 2019

Available Online:

10 December 2019
In the present study, highest TSS content was recorded in ferigation treatment $\mathrm{F}_{1}\left(14.32^{\circ}\right.$ Brix $)$, pruning treament while it was not affected by pruning and crops load treatments. Among all fertigation treatments, the highest total sugar $(9.24 \%)$ was registered in fertigation treatment $\mathrm{F} 1$ while highest total sugar was recorded in pruning treatment $\mathrm{P}_{1}(8.82 \%)$ and among crops load, $\mathrm{C}_{1}$ treatment recorded highest sugar content $(9.14 \%)$. The reducing sugar content was estimated highest in fertigation treatment $F_{1}$ (8.05 per cent), pruning treatment $\mathrm{P}_{2} 7.81(\%)$ and crops load treatment in $\mathrm{C}_{1}$ (7.85 per cent). The minimum titrable acidity was recorded in treatments $F_{1}(0.68 \%)$ while in pruning treament $\mathrm{P}_{1}$ recorded minimum value $(0.73 \%)$ of titrable acidity and in crops load treatment $\mathrm{C}_{1}(0.72 \%)$. The maximum sugar acid ratio was recorded $12.41 \%, 11.84 \%, 12.27 \%$ in treatment of fertigation $\mathrm{F}_{1}$, pruning treatment $\mathrm{P}_{2}$ and crop load trearment $\mathrm{C}_{1}$, respectively. The ascorbic acid content was recorded highest in fertigtion treatment $F_{1}\left(15.40 \mathrm{mg} \mathrm{g}^{-1}\right)$, pruning treatment $\mathrm{P}_{2}\left(14.40 \mathrm{mg} \mathrm{g}^{-1}\right)$ and crop load treatment $\mathrm{C}_{1}\left(12.98 \mathrm{mg} \mathrm{g}^{-1}\right)$

\section{Introduction}

Pomegranate (Punica granatum L.) is one of the most emerging fruit-crops of India. It is generally known in a distinct family Lythraceae, which comprises only one genus (Punica) and two species; $P$. granatum and $P$. protopunica (Samir, 2010). The pomegranate is an ancient, mystical, unique fruit borne on a small, long-living tree cultivated throughout the Mediterranean region. Pomegranate is considered native to Iran, Afghanistan and Southern Pakistan's Baluchistan region to the Himalayas in Northern India. Pomegranate is loaded with tannins, anthocyanins, polyphenolics and antioxidant vitamins, A, E and $\mathrm{C}$, all of which have a health effect on the body. Wild pomegranate is too acidic value of preparing the 'Anardana'. India is the largest producer of pomegranate in the world. The 
recent area and production of pomegranate is $0.2 \mathrm{mh}$ and $2.4 \mathrm{mT}$, respectively (NHB, 2017). In India, pomegranate is commercially cultivated in Solapur, Nasik, Ahmed Nagar, Dhule, and Latur districts of Maharashtra and the extended to Gujarat, Andhra Pradesh, Rajasthan and Tamil Nadu. The different commercial varieties of pomegranates produced in the above areas are Ganesh, Bhagwa, Mridula, Ruby and Arakta. The export of pomegranate is estimated 49.76 thousand MT which was value of 49.04 crore Rs. (NHB, 2017).

Excessive fruits per tree decrease fruit size and quality, consume tree reserves (Dennis, 2000). Only the balanced distribution of assimilation products in the organs of sink and source can guarantee the high economic yield. Therefore, it is of great significance to adjust the "sink-source" relationship in fruit trees for the growth and development of fruit and fruit quality. Moreover, the consistent production of fruit of optimum colour and size can only be accomplished, when a proper balance between the vegetative growth and fruiting is maintained (Reginato, 2002). This can be improved by pruning of pomegranate tree at optimum level. Pomegranate tree bloom abundantly and set fruits excessively, which in the main cause for the variability in size of fruit. So in order to improve the color and size of fruits, it is imperative to optimize the fruit load in pomegranate by thinning operation. Fertigation is important technique to improve the productivity of crop by increasing the water use and fertilizer use efficiency of crop. So combined effect of pruning intensities, crop load and fertigation was conducted in the study.

\section{Materials and Methods}

The field experiment was conducted at Horticulture farm, Rajasthan Agricultural Research Institute, Durgapura (Jaipur-
Rajasthan) during 2015-16 and 2016-17. The experiment was conducted during JanuaryAugust cropping season (Based on Ambe bahar flowering that occur in FebruaryMarch). The trees were three years old. The pruning treatments imposed end of December when plants were under dormant condition. The previous season (Mrig bahar) shoots were prunned.

The experiment, comprised of 18 treatment combination replicated four times, was laid out in split plot design with three fertigation treatments i.e. F1 (100\%), F2 (75\%) and F3 $(50 \%)$ under main plots, two levels of pruning intensities i.e. $\mathrm{P} 1$ (pruning of one year shoot to $25 \%$ ) and $\mathrm{P} 2$ (pruning of one year shoot to 50 $\%)$ and three levels of crop loads i.e. C1 (20 fruits), C2 (30 fruits) and C3 (40 fruits) were added in sub plots. The trees were three years old. The pruning treatments imposed end of December when plants were under dormant condition. The previous season (Mrig bahar) shoots were prunned. The fertigation schedule (250:125:125 and 500:125:125 g plant-1 year1) for three and four year old pomegranate plants was fixed based on the recommendation given by Pareek, (1982). For fertigation, the above fertilizers were divided as per the stage of crop growth and applied twice a week

\section{Results and Discussion}

Mean value of total soluble solid content was maximum $\left(14.32^{\circ}\right.$ Brix $)$ in fertigation treatment $\mathrm{F}_{1}$ and it was followed by fertigation treatment $\mathrm{F}_{2}\left(14.24^{\circ}\right.$ Brix $)$. The lowest total soluble solid $\left(13.53^{\circ}\right.$ Brix) was recorded in treatment $\mathrm{F}_{3}$ in experiment. The total soluble solids were not affected by various level pruning and crop load treatments. The same trend was followed in pooled mean values of total sugars. The highest ( 9.24 per cent) total sugar was registered in 100 per cent RDF through fertigation followed by 75 per cent RDF through fertigation (9.21 per cent). The 
lowest (7.80 per cent) total sugar content was recorded by 50 per cent RDF through fertigation $\left(\mathrm{F}_{3}\right)$. The total sugar content was affected significantly by various level pruning treatments. The pooled mean value of total sugars was recorded highest in treatment $\mathrm{P}_{1}$ (8.82 per cent) and lowest in the treatment $\mathrm{P}_{2}$ (8.68 per cent). Significant difference was observed on total sugar content by different crop load treatments. Pooled mean value of total sugars content was the highest in crop load treatment $\mathrm{C}_{1}$ (9.14 per cent) and lowest total sugars content was recorded by crops load treatment $\mathrm{C}_{3}$ (8.40 per cent). The mean of reducing sugar content was the highest (8.05 per cent) in 100 per cent RDF fertigation treatment $\left(\mathrm{F}_{1}\right)$ followed by 75 per cent RDF through fertigation $\left(F_{2}\right)$ (7.96 per cent). The lowest reducing sugar was recorded by treatment $\mathrm{F}_{3}$ (7.02 per cent). The maximum (7.81 per cent) pooled value of reducing sugar content was recorded in treatment $\mathrm{P}_{2}$ while minimum (7.53 per cent) reducing sugar content recorded in the treatment $\mathrm{P}_{1}$. Pooled mean value of reducing sugar content (7.85 per cent) was the highest in treatment $C_{1}$ while lowest reducing sugar content was recorded by $\mathrm{C}_{2}$ treatment (7.39 per cent). Titrable acidity was significantly increased by application of 50 per cent RDF through fertigation.

The treatment $\mathrm{F}_{3}$ recorded the highest titrable acidity $(0.78 \%)$ while lowest titrable acidity was recorded in treatments $\mathrm{F}_{1}(0.68 \%)$. The maximum pooled value $(0.76$ per cent $)$ and minimum value $(0.73$ per cent $)$ of titrable acidity was recorded in treatment $\mathrm{P}_{2}$ and $\mathrm{P}_{1}$, respectively. The pooled mean value of titrable acidity highest in $C_{1}$ ( 0.76 per cent) which it at par with $\mathrm{C}_{2}$ (0.76 per cent) and lowest titrable acidity was recorded in $\mathrm{C}_{1}$ (0.72 per cent). Pooled mean value of sugar: acid ratio was the highest in 100 per cent $\mathrm{RDF}$ through fertigation (12.41 per cent) treatment while the lowest sugar:acid ratio (10.46 per cent) was recorded by treatment $F_{3}$. The pooled mean value of sugar acid ratio was recorded highest in treatment $\mathrm{P}_{2}$ (11.84) and lowest in the treatment $P_{1}$ (11.65). The pooled value of sugar:acid ratio was significantly higher in treatment $\mathrm{C}_{1}$ i.e. 12.27 and lower sugar:acid ratio in treatment $\mathrm{C}_{3}$ i.e. 11.27. The application of 100 per cent RDF through fertigation i.e. $\mathrm{F}_{1}$ registered the highest ascorbic acid content $\left(15.40 \mathrm{mg} \mathrm{g}^{-1}\right)$. It was followed by $\mathrm{F}_{2}$ (application of 75 per cent RDF through fertigation) $\left(14.22 \mathrm{mg} \mathrm{g}^{-1}\right)$. The lowest ascorbic acid content (11.78 $\left.\mathrm{mg} \mathrm{g}^{-1}\right)$ was recorded in treatment $\left(\mathrm{F}_{3}\right) 50$ per cent RDF through fertigation. The pooled mean value of ascorbic acid content was registered (14.33 $\mathrm{mg} \mathrm{g}^{-1}$ ) maximum in $\mathrm{C}_{1}$ treatment whereas, minimum (12.98 $\left.\mathrm{mg} \mathrm{g}^{-1}\right)$ in treatment $\mathrm{C}_{3}$.

The quality improvement might be due to the involvement of $\mathrm{k}$ in carbohydrate synthesis, breakdown and translocation of starch, synthesis of protein and neutralization of physiologically important organic acids (Tisdale and Nelson, 1966). Moreover, the availability of adequate soil moisture with required quantity of nutrients might have resulted in more uptake of nutrients favoured by a profused rooting system of plants. This has led to a balanced water and nutrition supply to the plants and thereby increased the quality of pomegranate fruits. These are in line with the findings of Kadam and Mayar (1992) and Bafna et al., (1993). With regard to NPK levels, the highest TSS, total sugars, non reducing sugars, and sugar: acid ratio contents were registered by 100 per cent RDF whereas, the lowest levels of these traits were noticed in the treatments providing lower dose of fertigation. So, it is self-explanatory that to attain a higher fruit quality of pomegranate, the major nutrients like NPK should be given at optimum doses (Table 1-3). 
Table.1 Recommended fertilizer schedule below given at different stages

\begin{tabular}{|c|c|c|c|c|c|c|c|c|}
\hline \multirow{3}{*}{$\begin{array}{l}\text { Nutrient } \\
\text { Plant }^{-1}\end{array}$} & \multicolumn{8}{|c|}{ Stage of application } \\
\hline & \multicolumn{2}{|c|}{$\begin{array}{c}\text { Vegetative } \\
\text { stage } \\
\text { (September- } \\
\text { November) }\end{array}$} & \multicolumn{2}{|c|}{$\begin{array}{c}\text { Stress } \\
\text { period } \\
\text { (December) }\end{array}$} & \multicolumn{2}{|c|}{$\begin{array}{c}\text { Flowering to } \\
\text { fruit set stage } \\
\text { (January- } \\
\text { February) }\end{array}$} & \multicolumn{2}{|c|}{$\begin{array}{c}\text { Fruit development } \\
\text { stage } \\
\text { (March-May) }\end{array}$} \\
\hline & 2015 & 2016 & 2015 & 2016 & 2015 & 2016 & 2015 & 2016 \\
\hline $\mathbf{N}(\mathbf{g})$ & 150 & 300 & - & - & 50 & 100 & 50 & 100 \\
\hline $\mathbf{P}(\mathbf{g})$ & 50 & 50 & - & - & 62.5 & 62.5 & 12.5 & 12.5 \\
\hline $\mathbf{K}(\mathbf{g})$ & 25 & 25 & - & - & 37.5 & 37.5 & 62.5 & 62.5 \\
\hline
\end{tabular}

Table.2 Effect of pruning intensity, crop load, fertigation on TSS, total sugar and reducing sugar

\begin{tabular}{|c|c|c|c|c|c|c|c|c|c|}
\hline \multirow{2}{*}{$\begin{array}{l}\text { Tre } \\
\text { atm } \\
\text { ents }\end{array}$} & \multicolumn{3}{|c|}{$\operatorname{TSS}\left({ }^{0} \mathbf{B}\right)$} & \multicolumn{3}{|c|}{ Total sugar (\%) } & \multicolumn{2}{|c|}{$\begin{array}{c}\text { Reducing sugar } \\
(\%)\end{array}$} & \multirow[b]{2}{*}{ Pooled } \\
\hline & $\begin{array}{c}2016- \\
17\end{array}$ & 2017-18 & Pooled & 2016-17 & 2017-18 & Pooled & 2016-17 & $2017-18$ & \\
\hline \multicolumn{10}{|c|}{ Fertigation } \\
\hline $\mathbf{F}_{1}$ & 14.27 & 14.37 & 14.32 & 9.17 & 9.32 & 9.24 & 7.99 & 8.11 & 8.05 \\
\hline $\mathbf{F}_{2}$ & 14.15 & 14.32 & 14.24 & 9.14 & 9.28 & 9.21 & 7.90 & 8.02 & 7.96 \\
\hline $\mathbf{F}_{3}$ & 13.49 & 13.58 & 13.53 & 7.73 & 7.86 & 7.80 & 6.96 & 7.07 & 7.02 \\
\hline $\begin{array}{c}\text { SE } \\
\mathbf{m}\end{array}$ & 0.32 & 0.34 & 0.30 & 0.16 & 0.17 & 0.16 & 0.19 & 0.14 & 0.14 \\
\hline CD & 0.92 & 0.94 & 0.92 & 0.56 & 0.57 & 0.57 & 0.66 & 0.50 & 0.49 \\
\hline \multicolumn{10}{|c|}{ Pruning } \\
\hline $\mathbf{P}_{1}$ & 14.06 & 14.21 & 14.13 & 8.61 & 8.75 & 8.68 & 7.48 & 7.59 & 7.53 \\
\hline $\mathbf{P}_{2}$ & 13.88 & 13.97 & 13.93 & 8.75 & 8.89 & 8.82 & 7.76 & 7.87 & 7.81 \\
\hline $\begin{array}{c}\text { SE } \\
\mathbf{m}\end{array}$ & 0.26 & 0.27 & 0.27 & 0.13 & 0.13 & 0.13 & 0.09 & 0.10 & 0.09 \\
\hline CD & NS & NS & NS & 0.38 & 0.39 & 0.38 & 0.27 & 0.30 & 0.28 \\
\hline \multicolumn{10}{|c|}{ Crop load } \\
\hline $\mathbf{C}_{1}$ & 14.01 & 14.14 & 14.07 & 9.07 & 9.21 & 9.14 & 7.79 & 7.91 & 7.85 \\
\hline $\mathbf{C}_{2}$ & 14.01 & 14.15 & 14.08 & 8.64 & 8.78 & 8.71 & 7.33 & 7.44 & 7.39 \\
\hline $\mathbf{C}_{3}$ & 13.90 & 13.97 & 13.94 & 8.33 & 8.47 & 8.40 & 7.73 & 7.85 & 7.79 \\
\hline $\begin{array}{c}\text { SE } \\
\text { m }\end{array}$ & 0.32 & 0.33 & 0.33 & 0.16 & 0.16 & 0.16 & 0.12 & 0.12 & 0.12 \\
\hline CD & NS & NS & NS & 0.46 & 0.47 & 0.46 & 0.33 & 0.33 & 0.33 \\
\hline
\end{tabular}


Table.3 Effect of pruning intensity, crop load, fertigation on titrtable acidity, sugar-acid ratio and ascorbic acid content

\begin{tabular}{|c|c|c|c|c|c|c|c|c|c|}
\hline \multirow[t]{2}{*}{$\begin{array}{l}\text { Treat } \\
\text { ments }\end{array}$} & \multicolumn{3}{|c|}{ Titrtable acidity } & \multicolumn{3}{|c|}{ Sugar-acid ratio $(\%)$} & \multicolumn{2}{|c|}{$\begin{array}{c}\text { Ascorbic acid } \\
\text { content }(\mathrm{mg} / 100 \mathrm{~g})\end{array}$} & \multirow[b]{2}{*}{ Pooled } \\
\hline & $\begin{array}{c}201 \\
6-17\end{array}$ & $2017-18$ & Pooled & $\begin{array}{c}2016- \\
17\end{array}$ & $2017-18$ & Pooled & 2016-17 & $2017-18$ & \\
\hline \multicolumn{10}{|c|}{ Fertigation } \\
\hline $\mathbf{F}_{1}$ & 0.67 & 0.70 & 0.68 & 12.53 & 12.29 & 12.41 & 15.33 & 15.46 & 15.40 \\
\hline $\mathbf{F}_{2}$ & 0.76 & 0.79 & 0.77 & 12.48 & 12.24 & 12.36 & 14.16 & 14.28 & 14.22 \\
\hline $\mathbf{F}_{3}$ & 0.77 & 0.80 & 0.78 & 10.57 & 10.36 & 10.46 & 11.73 & 11.83 & 11.78 \\
\hline SEm & 0.49 & 0.02 & 0.01 & 0.22 & 0.22 & 0.22 & 9.73 & 0.29 & 0.29 \\
\hline CD & 1.69 & 0.06 & 0.04 & 0.77 & 0.76 & 0.76 & 33.65 & 1.00 & 0.99 \\
\hline \multicolumn{10}{|c|}{ Pruning } \\
\hline $\mathbf{P}_{1}$ & 0.75 & 0.77 & 0.76 & 11.76 & 11.53 & 11.65 & 13.15 & 13.26 & 13.20 \\
\hline $\mathbf{P}_{2}$ & 0.72 & 0.75 & 0.73 & 11.96 & 11.73 & 11.84 & 14.33 & 14.46 & 14.40 \\
\hline SEm & 0.01 & 0.02 & 0.01 & 0.18 & 0.18 & 0.18 & 0.29 & 0.30 & 0.29 \\
\hline CD & 0.03 & 0.04 & 0.03 & 0.51 & 0.50 & 0.51 & 0.84 & 0.84 & 0.84 \\
\hline \multicolumn{10}{|c|}{ Crop load } \\
\hline $\mathbf{C}_{1}$ & 0.71 & 0.73 & 0.72 & 12.39 & 12.15 & 12.27 & 14.27 & 14.39 & 14.33 \\
\hline $\mathbf{C}_{2}$ & 0.75 & 0.78 & 0.76 & 11.81 & 11.58 & 11.69 & 14.02 & 14.15 & 14.08 \\
\hline $\mathbf{C}_{3}$ & 0.74 & 0.77 & 0.76 & 11.38 & 11.16 & 11.27 & 12.93 & 13.04 & 12.98 \\
\hline SEm & 0.01 & 0.02 & 0.01 & 0.22 & 0.22 & 0.22 & 0.36 & 0.36 & 0.36 \\
\hline CD & 0.03 & 0.04 & 0.03 & 0.63 & 0.62 & 0.62 & 1.02 & 1.03 & 1.03 \\
\hline
\end{tabular}

The effect was more pronounced when the same is given through fertigation. Similar observations were made by Koo (1984) in orange, Colapietra (1987) in grapes and Orphanos and Eliades (1994) in Valencia orange and Sadarunnisa et al., (2010) in papaya.

The data on effect of pruning and crop load on quality parameters like total soluble solid, organic acid, TSS: Acidity ratio reducing sugar, non reducing sugar, and ascorbic acid. Effect of total soluble solids due to pruning and fruit load had no significant difference amongst irrespective of fruit load and severity of pruning. Similar findings was correlated with the findings of Chandal (2004), Ibrahim et al., (1996) Matsumot and Koroda (1982) The data on effect of pruning and crop load revealed that pruning and crop load increased the total sugar. However, the highest total sugar percentage was found in sever pruning. This finding was accordance to the Nath (1994) and Sheikh et al., (1996). Effect of pruning and fruit load on titrable acidity was significant. Severity of pruning reduced the titrable acidity compared to light pruning. Similar finding was correlated with Tomita and Natsumi (1978).

\section{References}

Samir Z., 2010. In vitro Salt and Drought Tolerance of Manfalouty and Nab ElGamal Pomegranate Cultivars. Australian. Basic Appl. Sci. 4(6): 10761082.

Dennis, F. G. Jr., 2000. The history of fruit thinning. Plant Growth Reg. 31:1-16.

Pareek, O. P., 1982. Pomegranate research report and appraisal. Tech. Doc. No.8, 
AICFIP on arid zone fruits

Chandal, J. S., Bharti, O. A. and Rana, R. K., 2004. Effect of pruning severity on growth yield and fruit quality of kiwi fruit (Actinidia diliciosa). Indian $J$. Hort., 61 (2): 114-117.

Ibrahim, H. A., Ihsan, A. S., Waadallab, A. H. and Jaifer, S. S., 1996, Effect of lengh and diameter of canes on the yield, physical, mechanical and chemical properties of grape cultivars deiss anv. Mysore J Agric. Sci., 30: 67-75.

Matsumoto, Y. and Koronda, K., 1982, Studies on bud and fruit thinning of Japanese perimon. The establishment of the standard of thinning to obtain large $c v$. Fayu fruits. Bulletin Nara
Agriculture experiment station. 13: 920.

Nath, J. C., 1994, Effect of pruning intensity on growth, yield and quality of Assam lemon (Citrus limon Burn). Haryana J. Hort. Sci., 23 (4): 281-285

Sheikh, M. K., 1999, Studies on the effect of horticultural practices on yield and quality of pomegranate (Punica granatum L.) $c v$. Ganesh in Northern Dry Zone of Karnataka. Ph.D. Thesis, Uni. Agric. Sci., Dharwad (India).

Tomita, E. and Natsumi, K., 1978. Effect of time of fruit thinning on fruit growth and sugar and acid content of the juice of citrus Hassaku. J. Japanese Soc. Horti. Sci., 47: 158-166.

\section{How to cite this article:}

Dinesh Nagar, K. K. Meena, S. Mukherjee and Sourabh Garg. 2019. Influence of Pruning Intensity, Crop Load and Fertigation on Quality Attribute of Pomegranate Cv. Bhagwa. Int.J.Curr.Microbiol.App.Sci. 8(12): 1663-1668. doi: https://doi.org/10.20546/ijcmas.2019.812.199 